\title{
A Molecular Mechanism for Ibuprofen-Mediated RhoA Inhibition in Neurons
}

\author{
John Dill, Ankur R. Patel, Xiao-Li Yang, Robert Bachoo, Craig M. Powell, and Shuxin Li \\ Department of Neurology and Neuroscience Graduate Program, University of Texas Southwestern Medical Center, Dallas, Texas 75390-8813
}

\begin{abstract}
Ibuprofen is a nonsteroidal anti-inflammatory drug widely used to relieve pain and inflammation in many disorders via inhibition of cyclooxygenases. Recently, we have demonstrated that ibuprofen inhibits intracellular signaling of RhoA and promotes significant axonal growth and functional recovery following spinal cord lesions in rodents. In addition, another study suggests that ibuprofen reduces generation of amyloid- $\beta 42$ peptide via inactivation of RhoA signaling, although it may also regulate amyloid- $\beta 42$ formation by direct inhibition of the $\gamma$-secretase complex. The molecular mechanisms by which ibuprofen inhibits the RhoA signal in neurons, however, remain unclear. Here, we report that the transcription factor peroxisome proliferator-activated receptor $\gamma(\operatorname{PPAR} \gamma)$ is essential for coupling ibuprofen to RhoA inhibition and subsequent neurite growth promotion in neurons. Ibuprofen activates PPAR $\gamma$ in neuronlike PC12 and B104 cells. Activation of PPAR $\gamma$ with traditional agonists mimics the RhoA-inhibiting properties of ibuprofen in PC12 cells and, like ibuprofen, promotes neurite elongation in primary cultured neurons exposed to axonal growth inhibitors. Protein knockdown with small interfering RNA specific for PPAR $\gamma$ blocks RhoA suppression of PPAR $\gamma$ agonists in PC12 cells. Moreover, the effect of ibuprofen on RhoA activity and neurite growth in neuronal cultures is prevented by selective PPAR $\gamma$ inhibition. These findings support that PPAR $\gamma$ plays an essential role in mediating the RhoA-inhibiting effect of ibuprofen. Elucidation of the novel molecular mechanisms linking ibuprofen to RhoA inhibition may provide additional therapeutic targets to the disorders characterized by RhoA activation, including spinal cord injuries and Alzheimer's disease.
\end{abstract}

\section{Introduction}

Ibuprofen is a nonsteroidal anti-inflammatory drug (NSAID) widely used to treat mild to moderate pain and inflammation in arthritis, primary dysmenorrhea, headache, and many other disorders. It is a major medicine in the Essential Drugs List of the World Health Organization and available over the counter in most areas. The major molecular binding partners for NSAIDs are cyclooxygenases, but some NSAIDs have other targets, including nuclear factor- $\kappa \mathrm{B}$, peroxisome proliferator-activated receptor $\gamma(\operatorname{PPAR} \gamma)$, and RhoA (Kashfi and Rigas, 2005). Several NSAIDs, including ibuprofen, have been shown to reduce the risk of Alzheimer's disease via the mechanisms independent of cyclooxygenase inhibition (Weggen et al., 2001), although clinical trials with some NSAIDs did not show beneficial effects for Alzheimer's disease patients (de Jong et al., 2008; Pasqualetti et al., 2009). Subsequent studies demonstrate that certain NSAIDs may inhibit the formation of amyloid- $\beta 42$, a critical peptide leading to pathogenic cascade in Alzheimer's disease via suppression of the $\gamma$-secretase complex (Eriksen et al., 2003; Weggen et al., 2003). Another study, however, suggests that ibuprofen and two

Received 0ct. 9, 2009; revised Nov. 11, 2009; accepted Nov. 24, 2009.

This work was supported in part by research grants from Paralyzed Veterans of America (S.L.), the Crowley Family Foundation, the VanBeber family, Crystal Charity Ball Funds, and the Lowe Foundation (C.M.P.). We thank Drs. Jon Graff and Lily Jiang at University of Texas Southwestern Medical Center for providing PPRE-x3-TK-Luc reporter vector and for assisting luciferase activity measurements.

Correspondence should be addressed to Shuxin Li, Department of Neurology, University of Texas Southwestern Medical Center at Dallas, 5323 Harry Hines Boulevard, Dallas, TX 75390-8813. E-mail: shuxin.li@utsouthwestern.edu.

DO1:10.1523/JNEUROSCI.5045-09.2010

Copyright $\odot 2010$ the authors $\quad 0270-6474 / 10 / 300963-10 \$ 15.00 / 0$ other NSAIDs reduce amyloid- $\beta 42$ generation via inactivation of RhoA (Zhou et al., 2003), suggesting RhoA-inhibiting properties of certain NSAIDs. RhoA activation may also be critical in mediating multiple biological activities during the pathogenesis of multiple sclerosis, including immune reactions, invasion of leukocytes into the CNS, survival of myelinating oligodendrocytes, and demyelination (Walters et al., 2002; Mi et al., 2005).

As the downstream signal for multiple extracellular molecules, RhoA activation plays a critical role in limiting axonal regeneration and in inducing glial apoptosis following CNS axonal injuries (Dubreuil et al., 2003; McGee and Strittmatter, 2003; McKerracher and Higuchi, 2006). CNS lesions upregulate RhoA protein expression in rodents (Schwab et al., 2004; Conrad et al., 2005) and patients (Brabeck et al., 2004) and trigger RhoA activation in injured spinal cord days to weeks after trauma (Dubreuil et al., 2003; Madura et al., 2004; Yamagishi et al., 2005). Inhibition of RhoA with C3 transferase or its downstream kinase with Y-27632 or fasudil improves recovery from spinal cord injuries in rodents (Dergham et al., 2002; Fournier et al., 2003; Tanaka et al., 2004). Thus, regulation of RhoA activity is an important therapeutic target for axonal repair in injured CNS neurons. More recently, we have demonstrated that RhoA inhibition with ibuprofen stimulates remarkable axonal growth and promotes functional recovery in the lesioned CNS using spinal cord injury models (Fu et al., 2007), suggesting the therapeutic potential of ibuprofen as a RhoA inhibitor in treating CNS injuries characterized by axonal disconnection. Our initial finding has been independently replicated in other spinal cord injury models (Wang et al., 2009). 
Given the critical functions of RhoA in regulating the pathologic processes of a number of neurological disorders and the extensive use of ibuprofen in humans, it is critical to elucidate the molecular mechanisms by which ibuprofen inhibits RhoA signaling in neurons. Here, we report that the transcription factor PPAR $\gamma$ is essential for coupling ibuprofen to RhoA inhibition and the growth-promoting functions of this drug in neurons. Identification of this novel neuronal mechanism by which ibuprofen suppresses RhoA activation may be important for the rational development of therapeutics for a variety of CNS disorders exacerbated by RhoA activation.

\section{Materials and Methods}

Neuronal cell line cultures and PPAR $\gamma$ activity assay. PC12 cells were grown on collagencoated dishes in MEM Ham's nutrient medium F-12 supplemented with 5\% fetal bovine serum and $10 \%$ horse serum, 2 mm glutamine, $100 \mu \mathrm{g} / \mathrm{ml}$ penicillin, and $100 \mu \mathrm{g} / \mathrm{ml}$ streptomycin. These cells were differentiated for $48 \mathrm{~h}$ with nerve growth factor (NGF; $10 \mathrm{ng} / \mathrm{ml}$ ) in the same medium before receiving drug treatments or transfections. Rat B104 neuroblastoma cells were grown in complete culture medium containing DMEM supplemented with $10 \%$ fetal bovine serum, 2 mM L-glutamine, penicillin, and streptomycin. For PPAR $\gamma$ activity assays, PC12 and B104 cells were transfected with PPRE-x3-TK-Luc reporter vector in 24well plates. This vector contains three copies of PPAR response element (PPRE) upstream of the thymidine kinase promoter-luciferase fusion gene. Immediately or $24 \mathrm{~h}$ (for RNA interference experiments in Fig. 1C) following PPRE-x3-TK-Luc transfection, treatments with vehicle or various drugs were initiated, including ibuprofen (100-500 $\mu \mathrm{M})$, naproxen (100$500 \mu \mathrm{M})$, selective PPAR $\gamma$ agonists GW1929 $(10 \mu \mathrm{M})$ and rosiglitazone (Ros; $10 \mu \mathrm{M})$, or selective PPAR $\gamma$ antagonist GW9662 (5 or 10 $\mu \mathrm{M})$. Forty-eight hours after PPRE-x3-TK-Luc transfection, PC12 and B104 cells were prepared in reporter lysis buffer $(70 \mu \mathrm{l} /$ well $)$. Aliquots of cell lysates $(50 \mu \mathrm{l})$ were added to 96-well plates, and luciferase activities were assessed by measuring light production with a luminometer after adding $50 \mu \mathrm{l}$ of luciferase substrate (Promega) with two-channel injecting pumps to each well. Luciferase activity in cell lysates was normalized to total protein concentration determined by Bio-Rad DC protein assay reagents. All the PPRE-x3-TK-Luc transfection experiments were carried out in five or six replicates.

$R N A$ interference for PPAR $\gamma$. For RNA interference experiments, PC12 cells were plated in 24-well (for protein expression and activity assays of PPAR $\gamma$ ) or 6-well (for RhoA activity assay) plates. Two days after growth, $\mathrm{PC} 12$ cells were transfected with small interfering RNA (siRNA) specific for PPAR $\gamma$ (catalog \#sc-156077;
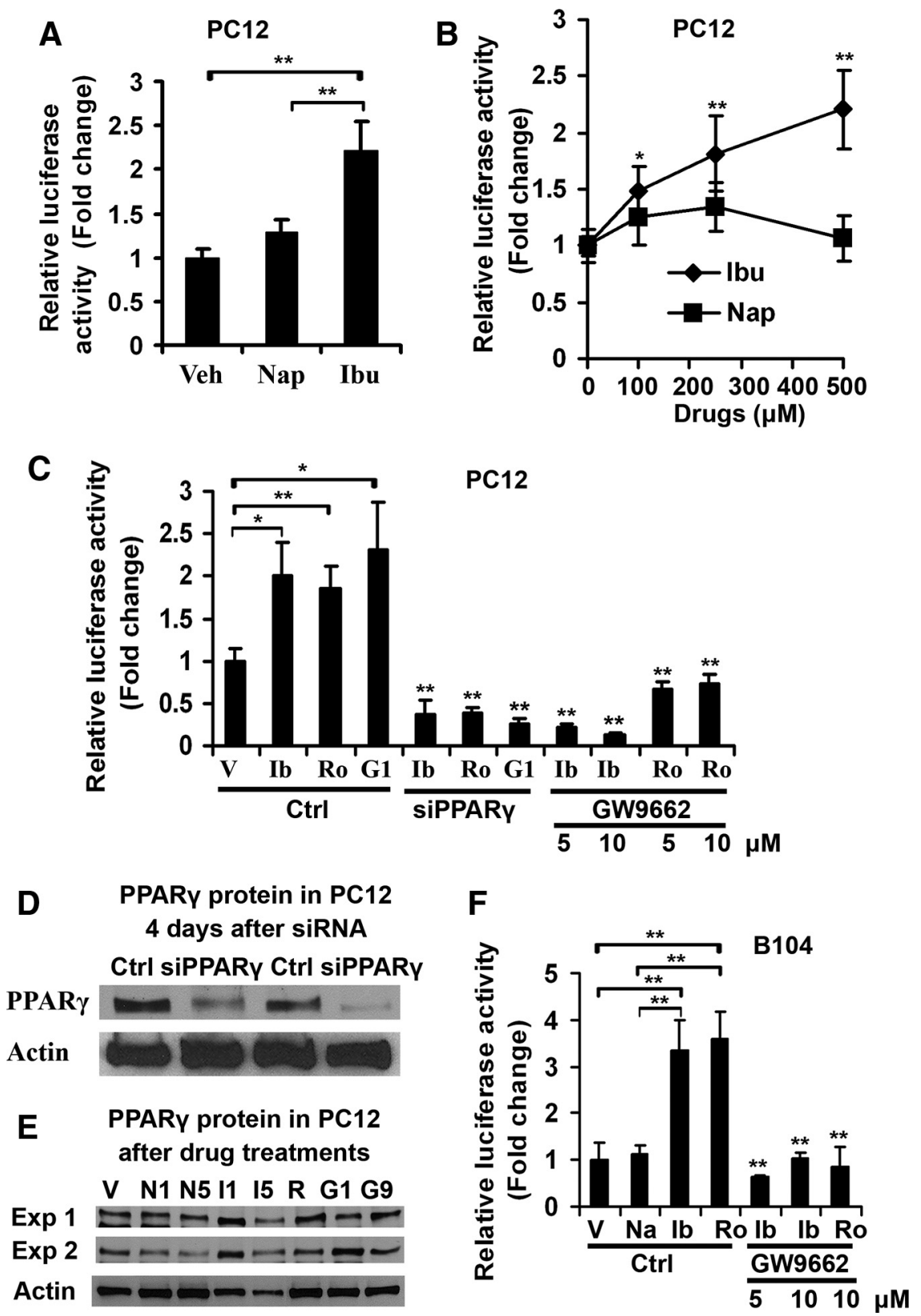

Figure 1. Ibuprofen activates PPAR $\gamma$ in PC12 and B104 neuron-like cells. A, Ibuprofen (Ibu; $500 \mu \mathrm{M})$, not naproxen (Nap; 400 $\mu \mathrm{M})$, remarkably increases PPAR $\gamma$ activity in PC12 cells transfected with the PPRE-x3-TK-Luc reporter vector. Veh, Vehicle. $B$, Ibuprofen (lbu) enhances luciferase activity in a dose-dependent manner in PC12 cells. In contrast, naproxen (Nap) does not have such an effect in PC12 cells. C, PPAR $\gamma$ activity was measured in PC12 cells $4 \mathrm{~d}$ after transfection with a control siRNA (Ctrl) or siPPAR $\gamma$. Ibuprofen (lb; $500 \mu \mathrm{m}), \mathrm{GW} 1929(\mathrm{G} 1 ; 10 \mu \mathrm{M})$, and rosiglitazone (Ro; $10 \mu \mathrm{M})$ significantly increase luciferase activity in $\mathrm{PC1} 2$ cells compared with cells treated with vehicle (V). However, PPAR $\gamma$ knockdown with siRNA or treatment with GW9662 (5 or $10 \mu \mathrm{M}$ ) completely blocked PPAR $\gamma$ activation induced by GW1929 and rosiglitazone. D. Western blot indicates the downregulation of PPAR $\gamma$ protein in PC12 cells $4 \mathrm{~d}$ after transfection with siPPAR $\gamma$ compared with the control (Ctrl). The bottom bands show actin protein determined from the same samples. Two sets of samples were employed and the same amount of protein was loaded in the control and siPPAR $\gamma$ samples. $\boldsymbol{E}$, Western blot indicates PPAR $\gamma$ protein expression in PC12 cells $2 \mathrm{~d}$ after treatments with vehicle (V), $100 \mu \mathrm{m}$ naproxen (N1), $500 \mu \mathrm{m}$ naproxen (N5), $100 \mu \mathrm{m}$ ibuprofen (11), $500 \mu \mathrm{m}$ ibuprofen (I5), rosiglitazone (R; $10 \mu \mathrm{M}$ ), GW1929 (G1; $10 \mu \mathrm{M})$, and GW9662 (G9, $10 \mu \mathrm{M})$. The bottom bands indicate actin protein measured from the samples in experiment 1 (Exp 1). The same amount of protein was used based on the total protein determination from these samples. $F$, lbuprofen (lb; $500 \mu \mathrm{M}$ ) and rosiglitazone (Ro; $10 \mu \mathrm{M}$ ) significantly enhance luciferase activities in B104 neuroblastoma cells but naproxen $(\mathrm{Na} ; 400 \mu \mathrm{M})$ does not,. In contrast, the PPAR $\gamma$ antagonist GW9662 (5 or $10 \mu \mathrm{M})$ effectively reverses the luciferase activity induced by ibuprofen or rosiglitazone in B104 cells. The results in graphs are expressed as the fold changes compared with the control (Ctrl) treated with vehicle $(V)$. Means \pm SEM from 5 to 10 samples are reported in each group. ${ }^{*} p<0.05 ;{ }^{* *} p<0.01$; compared with the indicated group $(\boldsymbol{A}, \boldsymbol{C}, \boldsymbol{F})$, vehicle-treated group $(\boldsymbol{B})$, or the group treated with the same drug without siPPAR $\gamma$ or GW9662 $(\boldsymbol{C}, \boldsymbol{F})$; Student's $t$ test. 


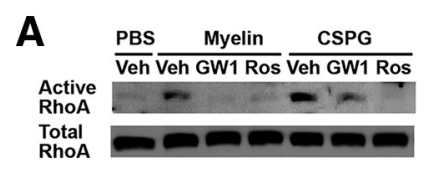

B

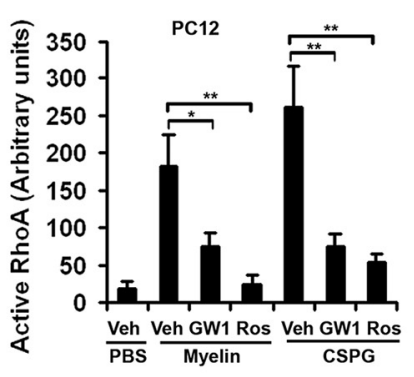

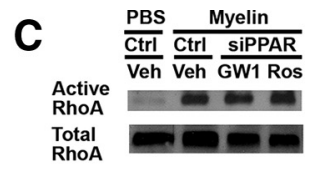

D

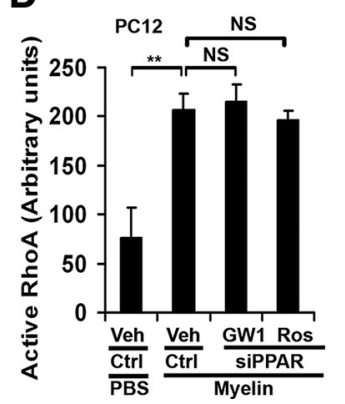

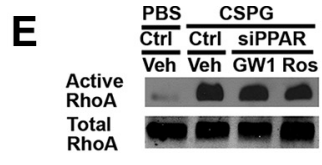

$\mathbf{F}$

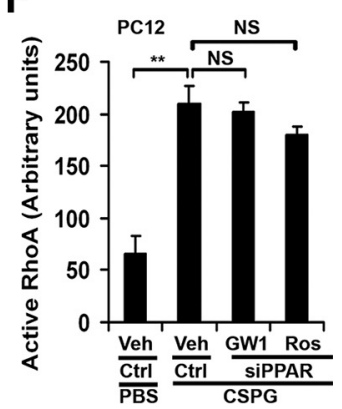

Figure 2. PPAR $\gamma$ agonists suppress RhoA activation induced by CNS myelin or CSPG in PC12 cells, and PPAR $\gamma$ knockdown with siRNA blocks this effect. $A$, RhoA activity (top bands) was determined from PC12 cell lysates $48 \mathrm{~h}$ after growth. Total RhoA protein (bottom bands) was determined from same cell lysates with blotting (20 $\mu \mathrm{g}$ of protein per lane). Veh, Vehicle; GW1, GW1929. $B$, Bar graph indicates densitometric measurements of RhoA activity from the lysates of PC12 cells exposed to CNS myelin or CSPG in the absence or presence of PPAR $\gamma$ agonists GW1929 (GW1) or Ros (10 $\mu \mathrm{M})$. Treatment with GW1929 or Ros strongly suppressed RhoA activation in PC12 cells induced by CNS myelin ( $50 \mu \mathrm{g} / \mathrm{ml} ; 30 \mathrm{~min})$ or CSPG (1.5 $\mu \mathrm{g} / \mathrm{ml} ; 30 \mathrm{~min})$. Veh, Vehicle. C, E, Top bands indicate active RhoA determined from PC12 cell lysates. PC12 cells were transfected with siPPAR $\gamma$ or a control siRNA (Ctrl). Four days after the transfection, cells were treated with vehicle (Veh), GW1929 (GW1), or Ros and stimulated with CNS myelin (C) or CSPG (E). Total RhoA protein (bottom bands) was detected from the same cell lysates with blotting. $\boldsymbol{D}, \boldsymbol{F}$, Bar graphs indicate densitometric measurements of RhoA activity from the lysates of PC12 cells treated with vehicle (Veh), GW1929 (GW1), or Ros (10 $\mu \mathrm{M}$ ) and stimulated with CNS myelin (D) or CSPG $(\boldsymbol{F})$. PPAR $\gamma$ knockdown with siRNA principally prevented the RhoA suppression induced by GW1929 or Ros following application of CNS myelin $(50 \mu \mathrm{g} / \mathrm{ml}, 30 \mathrm{~min} ; \boldsymbol{D})$ or CSPG $(1.5 \mu \mathrm{g} / \mathrm{ml}, 30 \mathrm{~min} ; \boldsymbol{F})$. Means \pm SEM from three or four separate experiments are reported. ${ }^{*} p<0.05$; ${ }^{* *} p<0.01$; NS, no significance; Student's $t$ test.

Santa Cruz Biotechnology) or with a control siRNA. The control siRNA does not match any mouse genomic sequence. For transfection in 24-well plates, $1.2 \mu \mathrm{l}$ of the transfection reagent Lipofectamine (Invitrogen) was diluted in $50 \mu \mathrm{l}$ of RPMI 1640 medium in each well. After 5 min of incubation at room temperature, $2.5 \mu \mathrm{l}$ of $10 \mu \mathrm{M}$ siRNA in $50 \mu \mathrm{l}$ of RPMI 1640 medium was mixed with $51.2 \mu$ l of diluted transfection reagent. Following 20 min of incubation, siRNA was added to PC12 cells in $500 \mu \mathrm{l}$ of medium per well and incubated at $37^{\circ} \mathrm{C}$. Two days following siRNA transfection, culture medium was replaced with antibiotic-free culture medium. Twelve hours later, cells were transfected with PPRE-x3-TKLuc reporter vector as described above for PPAR $\gamma$ activity assay. One day after the second transfection, cells were changed to normal culture medium. PC12 cells were incubated with vehicle dimethyl sulfoxide, GW1929, rosiglitazone, or GW9662 for $24 \mathrm{~h}$ in the RNA interference experiments to minimize the potential toxic effects of two transfections and drug treatments. After wash with cold PBS and preparation in reporter lysis buffer, PPAR $\gamma$ activity in PC12 lysates was measured as described above.

For siRNA transfection in six-well plates, $7.5 \mu \mathrm{l}$ of $10 \mu \mathrm{M}$ siRNA was applied to PC12 cells in $1.5 \mathrm{ml}$ of antibiotic-free culture medium per well. The cells were switched to normal culture medium $2 \mathrm{~d}$ after transfection. Four days after siRNA transfection, cells were treated with different drugs and stimulated with purified CNS myelin or chondroitin sulfate proteoglycans (CSPG; Millipore) (see Figs. 2C-F, 6). The active RhoA in the cell lysates was measured as described below.

RhoA activity assay in cell lysates. The levels of GTP-bound RhoA in cultured PC12 neuron-like cells were measured via precipitation with glutathione $S$-transferase (GST)-rhotekin binding domain (RBD) (Ren et al., 1999; Fu et al., 2007). After 48 h of growth in NGF medium in culture dishes $(60 \mathrm{~mm})$ or six-well plates, differentiated PC12 cells were incubated with PPAR $\gamma$ agonist GW1929 $(10 \mu \mathrm{M})$ or Ros $(10 \mu \mathrm{M})$ or PPAR $\gamma$ antagonist GW9662 (10 $\mu \mathrm{M})$ plus vehicle, naproxen $(400 \mu \mathrm{M})$, or ibuprofen $(500 \mu \mathrm{M})$ for $1 \mathrm{~h}$. Then, cells were stimulated with axonal growth inhibitors by adding purified CNS myelin $(50 \mu \mathrm{g} / \mathrm{ml})$ or CSPG $(1.5 \mu \mathrm{g} / \mathrm{ml})$ to culture medium for $30 \mathrm{~min}$. After a wash with ice-cold PBS, cells were prepared in $1 \mathrm{ml}$ of cold lysis buffer supplemented with protease inhibitors (1 $\mathrm{mm}$ phenylmethylsulfonyl fluoride, $2 \mathrm{~mm}$ orthovanadate, $10 \mu \mathrm{g} / \mathrm{ml}$ leupeptin, and $10 \mu \mathrm{g} / \mathrm{ml}$ aprotinin) and clarified by centrifugation at $15,000 \times g$ for $5 \mathrm{~min}$ at $4^{\circ} \mathrm{C}$. After total protein quantification in lysates with Bio-Rad DC protein assay reagents, samples containing the same amount of protein were incubated with RBD-coupled beads (45 $\mu \mathrm{g} /$ sample; Cytoskeleton) for $50 \mathrm{~min}$ at $4^{\circ} \mathrm{C}$. GTP-bound RhoA and total RhoA in the cell lysates were detected by Western blotting using a mouse monoclonal antibody against RhoA (catalog \#sc-418; Santa Cruz Biotechnology). Proteins were transferred to nitrocellulose membrane and bands were visualized with enhanced chemiluminescence reagents (GE Healthcare). For blot densitometry assay, the images of active RhoA bands were captured with a Bio-Rad Gel Doc XR documentation system, and the band density was determined using Quantity One software (Fu et al., 2007). The intensity of an individual band was calculated by subtraction of the background value on the same lane from which the band was measured.

Primary neuronal cultures and neurite outgrowth assay. Dorsal root ganglia (DRGs) were dissected out from C57BL/6 mice aged 7-10 weeks. After incubation with collagenase and $0.25 \%$ trypsin/EDTA and wash with culture medium, dissociated DRG neurons were plated onto plastic coverslips in a 24-well plate and grown in culture medium (F-12 plus $10 \%$ fetal bovine serum, $2 \mathrm{~mm}$ glutamine, $100 \mu \mathrm{g} / \mathrm{ml}$ penicillin, and $100 \mu \mathrm{g} / \mathrm{ml}$ streptomycin) for $24 \mathrm{~h}$ at $37^{\circ} \mathrm{C}$ in the absence of NGF (Dill et al., 2008). The primary cerebellar granular neuron (CGN) cultures were prepared from cerebelli of postnatal days 7-9 (P7-P9) C57BL/6 mice. After trypsin digestion, cells were dissociated and grown in culture medium (DMEM/F-12 containing 10\% fetal bovine serum, 2 mM glutamine, $100 \mu \mathrm{g} / \mathrm{ml}$ penicillin, $100 \mu \mathrm{g} / \mathrm{ml}$ streptomycin, $25 \mathrm{~mm}$ $\mathrm{KCl}$, and $25 \mathrm{~mm}$ glucose) for $24 \mathrm{~h}$ at $37^{\circ} \mathrm{C}$ (Dill et al., 2008). After coating with $100 \mu \mathrm{g} / \mathrm{ml}$ poly-L-lysine, cell culture coverslips were incubated with $10 \mu \mathrm{g} / \mathrm{ml}$ laminin for $2 \mathrm{~h}$ at $37^{\circ} \mathrm{C}$ before cell plating. In some cases, coverslips were coated with CNS myelin $(50 \mu \mathrm{g} / \mathrm{ml}$ for $30 \mathrm{~min})$ purified from bovine brain white matter, Nogo-P4 peptide (25 $\mu \mathrm{M}$ overnight; Alpha Diagnostics) or CSPG (1.5 $\mu \mathrm{g} / \mathrm{ml}$ for $30 \mathrm{~min})$ before coating with laminin. The dissociated neurons were treated with vehicle, GW1929 (10 $\mu \mathrm{M})$, or Ros $(10 \mu \mathrm{M})$ or with ibuprofen $(500 \mu \mathrm{M})$ plus GW9662 $(10 \mu \mathrm{M})$ or actinomycin D (ActD; $20 \mathrm{~nm}$; Sigma-Aldrich). For neurite outgrowth, DRG neurons or CGNs were fixed $24 \mathrm{~h}$ after plating and stained with rhodamine phalloidin (Invitrogen) or Tuj-1 (neuron-specific beta III tubulin) antibody. Images of each culture were captured with a Nikon image-collecting system, and neurite outgrowth was quantified with NIH Image software (Fu et al., 2007; Dill et al., 2008). For outgrowth quantification, the total neurite length for each neuron was determined from 40 to 150 representative DRG neurons or from 120 to 170 representative CGNs in each experiment. The mean values were calculated from four to six separate experiments.

\section{Results}

Ibuprofen activates PPAR $\gamma$ in neuron-like PC12 and neuroblastoma B104 cells

We hypothesize that activation of PPAR $\gamma$ is essential for coupling RhoA inactivation induced by ibuprofen in neurons. As an initial test of this hypothesis, we examined the effects of ibuprofen on $\operatorname{PPAR} \gamma$ activities in neuron-like PC12 cells. Based on the structural similarity between PPAR $\gamma$ agonists and certain NSAIDs, one group has demonstrated that ibuprofen and indomethacin 
bind and activate PPAR $\gamma$ in adipocyte cultures (Lehmann et al., 1997). Given the expression of PPAR $\gamma$ in various neuronal cells (Zhao et al., 2006; Sarruf et al., 2009), ibuprofen may have a similar effect on PPAR $\gamma$ activity in neurons. To test this, we transfected PC12 cells with PPRE-x3-TK-Luc reporter vector $48 \mathrm{~h}$ after differentiation with NGF $(10 \mathrm{ng} / \mathrm{ml})$. PPRE-x3-TK-Luc vector contains three copies of PPRE upstream of the thymidine kinase promoter-luciferase fusion gene and has been frequently used to assess $\operatorname{PPAR} \gamma$ activity in cultures using luciferase as a reporter gene (Kim et al., 1998; Suh et al., 2007). Immediately following transfection, we treated PC12 cells with vehicle, ibuprofen, or naproxen, a NSAID that does not have a Rho-inhibiting function (Zhou et al., 2003; Fu et al., 2007). Forty-eight hours after transfection and drug incubations, we prepared PC12 cells in reporter lysis buffer and measured luciferase activities in cell lysates with a 96-well plate reader. As shown in Figure 1, $A$ and $B$, ibuprofen at $500 \mu \mathrm{M}$ significantly enhanced luciferase activity in PC12 cells compared with vehicleor naproxen-treated cells. Dose-response analysis reveals that ibuprofen activates PPAR $\gamma$ in PC12 cells in a dose-dependent manner. In contrast, naproxen did not significantly alter luciferase activity in PC12 cells at the concentrations between 100 and $500 \mu \mathrm{M}$.

$\operatorname{PPAR} \gamma$ agonists have been frequently used to stimulate PPAR $\gamma$ activity in cell cultures. We next evaluated the effects of the selective PPAR $\gamma$ agonists GW1929 (10 $\mu \mathrm{M})$ and Ros $(10 \mu \mathrm{M})$ on PPAR $\gamma$ activation in PC12 cells $4 \mathrm{~d}$ after transfection with a control siRNA or the siRNA specific for PPAR $\gamma(\operatorname{siPPAR} \gamma)$. As predicted, both PPAR $\gamma$ agonists, as well as ibuprofen, significantly increased luciferase activity in PC12 cells (Fig. 1C). Protein knockdown with siPPAR $\gamma$ (Fig. 1D) or inhibition with antagonist GW9662 (5 or $10 \mu \mathrm{M})$, however, completely blocked the activating effects of ibuprofen and PPAR $\gamma$ agonists in PC12 cells. This experiment suggests that the PPRE-x3-TKLuc vector used in this study is a reliable assay for measuring PPAR $\gamma$ activity in cultures. Examination of protein expression in PC12 cells via Western blotting indicates similar levels of PPAR $\gamma$ protein following the drug treatments, except for naproxen $(500 \mu \mathrm{M})$ and ibuprofen (100 and $500 \mu \mathrm{M})$, respectively, which appeared to cause a moderate reduction and upregulation of PPAR $\gamma$ protein (Fig. $1 E$; supplemental Fig. 1, available at www.jneurosci.org as supplemental material).
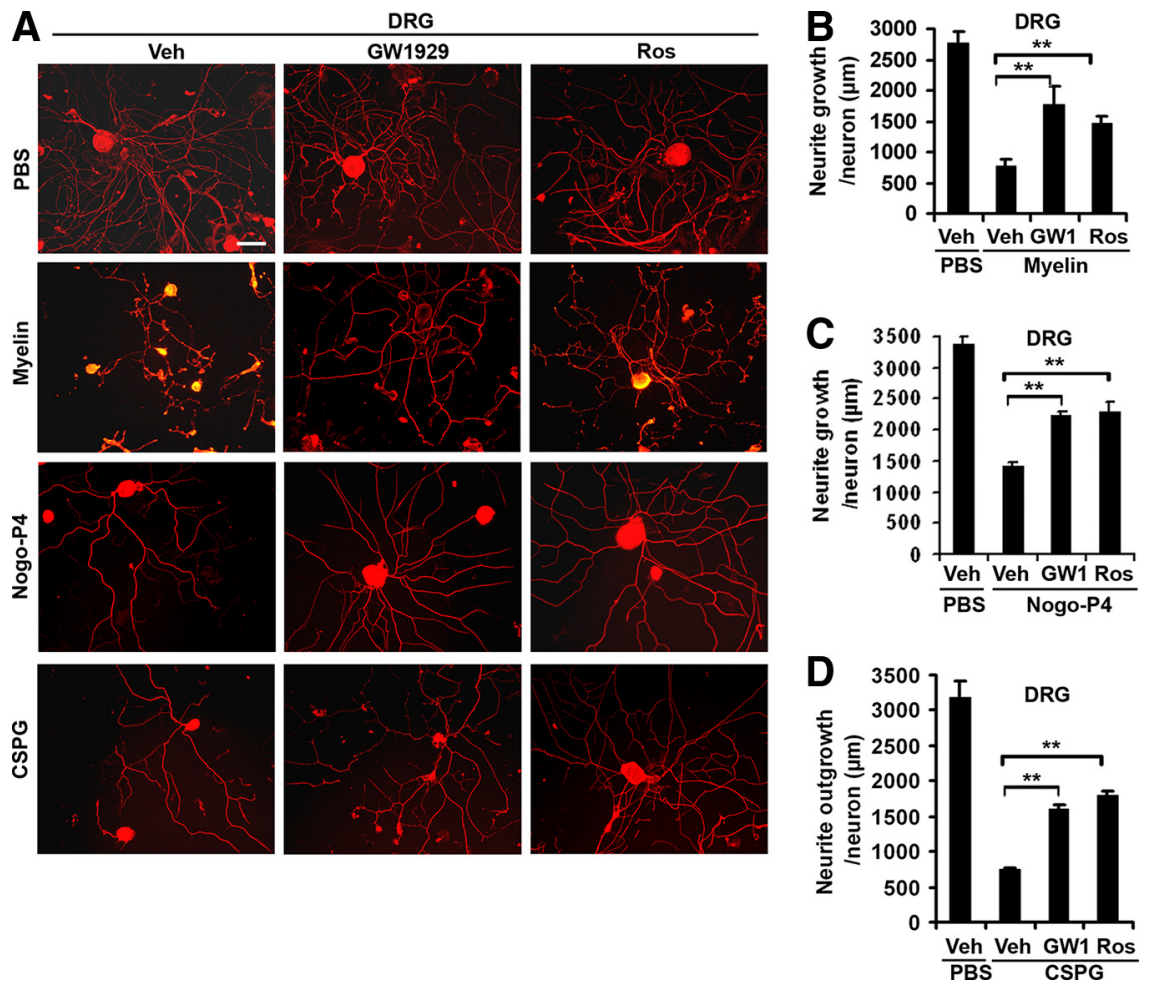

Figure 3. PPAR $\gamma$ activation with GW1929 or rosiglitazone stimulates neurite growth in mature DRG neurons cultured on CNS myelin $(\boldsymbol{A}, \boldsymbol{B}), \operatorname{Nogo}$-P4 $(\boldsymbol{A}, \boldsymbol{C}), \operatorname{orCSPG}(\boldsymbol{A}, \boldsymbol{D})$. $\boldsymbol{A}$, The representative DRG neuronal cultures derived from adult mice were treated with vehicle (Veh; left column), GW1929 (10 $\mu$ m; middle column), or rosiglitazone (10 $\mu \mathrm{m}$; right column) after cell plating in the absence or presence of CNS myelin $(50 \mu \mathrm{g} / \mathrm{ml})$, Nogo-P4 $(25 \mu \mathrm{m})$, orCSPG $(1.5 \mu \mathrm{g} / \mathrm{ml})$. Cells were fixedand stained with rhodamine phalloidin 24h after growth. Scale bar, $50 \mu \mathrm{m}$. B-D, The neurite length per DRG neuron was traced and quantified $24 \mathrm{~h}$ after cell plating. GW1, GW1929; Veh, vehicle. Means \pm SEM from four to six separate experiments are reported in each group. ${ }^{* *} p<0.01$; Student's $t$ test.
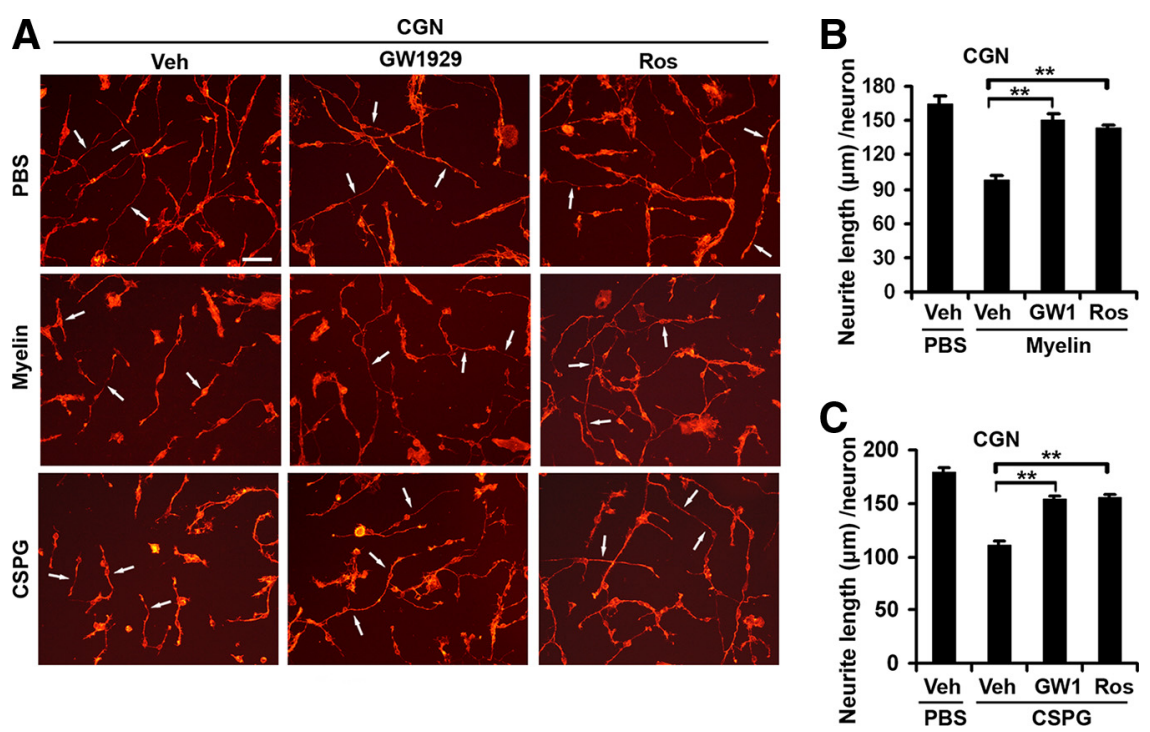

Figure 4. PPAR $\gamma$ agonists GW1929 and rosiglitazone stimulates neurite growth in postnatal CGNs cultured on CNS myelin or CSPG. A, The representative CGNs (arrows) from P7-P9 mice were treated with vehicle (Veh; left column), GW1929 (10 $\mu$ m; middle column), or rosiglitazone (10 $\mu \mathrm{m}$; right column) starting after cell plating in the absence (top row) or presence of CNS myelin (50 $\mu \mathrm{g} / \mathrm{ml}$; middle row) or CSPG $(1.5 \mu \mathrm{g} / \mathrm{ml}$, bottom row). CGNs were fixed and stained with rhodamine phalloidin $24 \mathrm{~h}$ after plating. Scale bar, $50 \mu \mathrm{m} . \boldsymbol{B}, \boldsymbol{C}$, The neurite length per CGN was traced and quantified $24 \mathrm{~h}$ after cell plating. GW1, GW1929; Veh, vehicle. Means \pm SEM from four to six separate experiments are reported in each group. ${ }^{* *} p<0.01$; Student's $t$ test.

To confirm the PPAR $\gamma$-activating properties of ibuprofen, we next measured the effects of ibuprofen or selective PPAR $\gamma$ ligands on PPAR $\gamma$ activities in B104 cultures, a neuroblastoma cell line derived from CNS. Like differentiated PC12 cells, B104 cells 
A

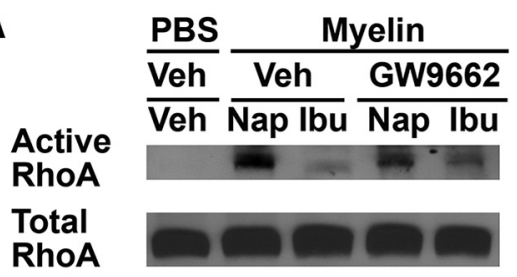

B

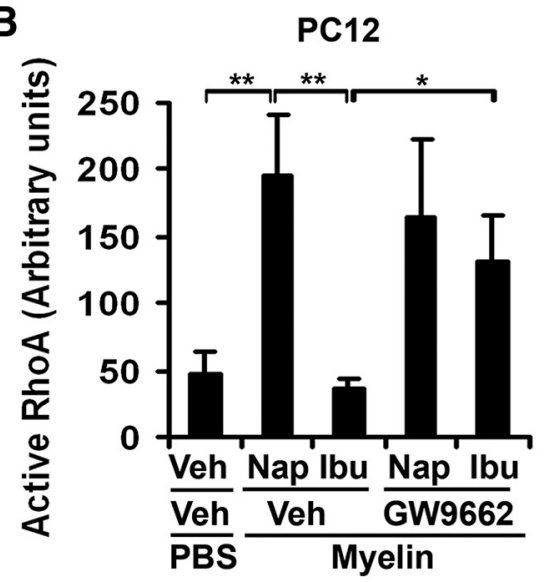

C

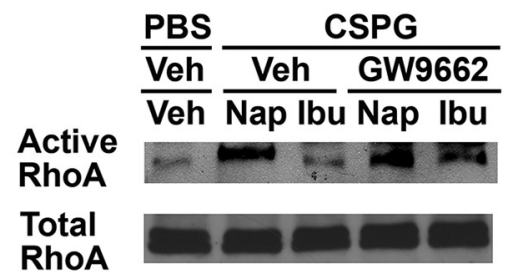

D

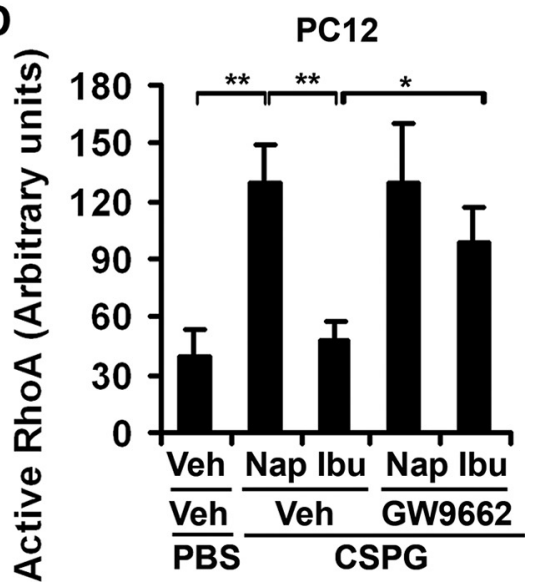

Figure 5. PPAR $\gamma$ antagonist GW9662 prevents RhoA inhibition function of ibuprofen in PC12 cells exposed to CNS myelin or CSPG. A, RhoA activity (top bands) was determined via GST-RBD binding and Western blotting from PC12 cells exposed to CNS myelin (50 $\mu \mathrm{g} / \mathrm{ml}$ ) for $30 \mathrm{~min}$. Total RhoA protein (bottom bands) was determined from the same cell lysates with blotting. Ibu, Ibuprofen; Nap, naproxen; Veh, vehicle. B, Bar graph indicates densitometric measurements of RhoA activity from PC12 cells treated with CNS myelin plus naproxen (Nap; $400 \mu \mathrm{M}$ ) or ibuprofen (Ibu; $500 \mu \mathrm{M}$ ) in the absence or presence of GW9662 $(10 \mu \mathrm{M})$. C, RhoA activity (top bands) was determined via GST-RBD binding and Western blotting from PC12 cells exposed to CSPG (1.5 $\mu \mathrm{g} / \mathrm{ml}$ ) for $30 \mathrm{~min}$. Total RhoA protein (bottom bands) was determined from the cell lysates via blotting. Ibu, Ibuprofen; Nap, naproxen; Veh, vehicle. $\boldsymbol{D}$, Bar graph indicates densitometry of RhoA activity from PC12 cells treated with CSPG plus naproxen (Nap; $400 \mu \mathrm{M}$ ) or ibuprofen (lbu; $500 \mu \mathrm{M})$ in the absence or presence of GW9662 (10 $\mu \mathrm{M})$. Treatment with ibuprofen $(500 \mu \mathrm{M})$, but not naproxen (400 $\mu \mathrm{M}$ ), suppressed RhoA activation principally in PC12 cells induced by CNS myelin $(\boldsymbol{A}, \boldsymbol{B})$ or CSPG $(\boldsymbol{C}, \boldsymbol{D})$. However, incubation with GW9662 mostly abolished the RhoA-repressing function of ibuprofen. Means \pm SEM from three to five separate experiments were reported in each group. ${ }^{*} p<0.05 ;{ }^{* *} p<0.01$; Student's $t$ test.

possess many neuronal properties, including morphological differentiation, electrophysiological responsiveness, and neurotransmitter synthesis. Consistently, ibuprofen and Ros (Fig. $1 F$ ) dramatically increased luciferase activities in lysates of B104 cells, but application of PPAR $\gamma$ antagonist GW9662 (5 or $10 \mu \mathrm{M})$ efficiently prevented PPAR $\gamma$ activation induced by ibuprofen and Ros. Together, our experiments suggest that ibuprofen is an effective activator of PPAR $\gamma$ in cells with neuronal properties.

PPAR $\gamma$ activation with agonists suppresses RhoA activity in PC12 cells exposed to CNS axon growth inhibitors

If PPAR $\gamma$ is responsible for the RhoA-suppressing function of ibuprofen in neurons, PPAR $\gamma$ activation with agonists should have a similar effect on RhoA activity. To test this hypothesis, we evaluated the alterations of RhoA activity in PC12 cells following stimulation with axonal growth inhibitors in the absence or presence of PPAR $\gamma$ agonists. After differentiation in NGF for $48 \mathrm{~h}$ and pretreatment with selective PPAR $\gamma$ agonist GW1929 $(10 \mu \mathrm{M})$ or Ros $(10 \mu \mathrm{M})$ for $1 \mathrm{~h}, \mathrm{PC} 12$ cells were stimulated with purified CNS myelin $(50 \mu \mathrm{g} / \mathrm{ml})$ or CSPG (a mixture of neurocan, phosphacan, versican, and aggrecan; $1.5 \mu \mathrm{g} / \mathrm{ml}$ ) for $30 \mathrm{~min}$. CNS myelin contains several inhibitory axonal growth components, including NogoA, myelin-associated glycoprotein, oligodendrocyte myelin glycoprotein, and netrin-1, and inhibits axon elongation via the membrane binding partners Nogo-66 receptor and paired-Ig like receptor-B (Fournier et al., 2001; Li et al., 2004; Atwal et al., 2008). Both CNS myelin and CSPG inhibitors are known to activate RhoA in neurons (McGee and Strittmatter, 2003). The active RhoA signal in PC12 cell lysates was determined via precipitation with RBD. Consistent with our recent report (Fu et al., 2007), both CNS myelin and CSPG dramatically increased active RhoA levels in neuronlike P12 cells $30 \mathrm{~min}$ after exposure. However, treatment with PPAR $\gamma$ agonist GW1929 or Ros significantly prevented RhoA activation induced by CNS myelin inhibitors or CSPG (Fig. 2A,B), although we observed the variability for RhoA activity assay between different experiments (Wang et al., 2009). Consistently, several groups have reported the high correlation between PPAR $\gamma$ activation and RhoA activities by demonstrating the potent RhoA-suppressing effect of PPAR $\gamma$ agonists in endothelial cells of brain microvessels, smooth muscle cells, and intestinal epithelial cells (Wakino et al., 2004; Chen et al., 2006; Ramirez et al., 2008).

To exclude the possible nonselective effect of PPAR $\gamma$ agonists and confirm the critical role of PPAR $\gamma$ activation in regulating RhoA activity in neuron-like cells, we next determined whether downregulation of PPAR $\gamma$ protein could prevent RhoA inactivation in PC12 cells induced by PPAR $\gamma$ agonists following stimulation with axon growth inhibitors. Four days after transfection with siPPAR $\gamma$ or a control siRNA, PC12 cells were treated with PPAR $\gamma$ agonists and stimulated with CNS myelin or CSPG. As predicted, transfection with siPPAR $\gamma$ almost completely blocked the RhoAsuppressing function of GW1929 and Ros in PC12 cells (Fig. $2 C-F)$. Taken together, our results support the remarkable role of PPAR $\gamma$ activation in regulating RhoA activity in neurons following stimulation with CNS substrates that inhibit axonal growth.

PPAR $\gamma$ activation promotes neurite outgrowth in primary cultured neurons exposed to axon growth inhibitors Given that RhoA activation dramatically restricts axon elongation (Dergham et al., 2002; Fu et al., 2007), RhoA inactivation with PPAR $\gamma$ agonists should overcome the growth restriction of CNS axon inhibitors. We tested this hypothesis by examining the effects of the PPAR $\gamma$ agonist GW1929 or Ros on neurite outgrowth in adult mouse DRG neurons exposed to CNS myelin or CSPG, two groups of major axon growth inhibitors in the CNS (McGee and Strittmatter, 2003). Because DRG neurons are very sensitive to various CNS axon growth inhibitors and physiologically possess both central and peripheral axons, this culture system is an excellent model for studying CNS axonal regeneration in vitro (Kim et al., 2006; Dill et al., 2008). Considering that CNS myelin contains multiple inhibitory components for axonal extension, in selected experiments we also tested whether PPAR $\gamma$ activation with agonists is able to overcome axon growth repression of myelin inhibitor NogoA using Nogo-P4. Nogo-P4 is a peptide derived from residues $31-55$ of Nogo-66 and has the inhibitory properties of Nogo-66, one of two inhibitory domains 
of NogoA (GrandPre et al., 2000; Alabed et al., 2007). CNS myelin, Nogo-P4, and CSPG dramatically reduce the neurite number and length in isolated DRG cultures. However, application of PPAR $\gamma$ agonist GW1929 $(10 \mu \mathrm{M})$ or Ros $(10 \mu \mathrm{M})$ significantly recovers the outgrowth of DRG neurons exposed to the inhibitory substrates compared with the cells treated with vehicle (Fig. 3A-D). This experiment suggests that PPAR $\gamma$ activation surmounts growth suppression by CNS axon growth inhibitors in mature neurons and mimics the neurite growth-promoting effects of ibuprofen and selective Rho inhibitors (Fu et al., 2007; Wang et al., 2009).

DRGs respond to various CNS inhibitory substrates, but they are ultimately peripheral neurons. Thus, we next assessed the neurite growth in cultured cerebellar granular neurons derived from P7-P9 mice, a type of central neuron widely used for studying axon growth in vitro (Wang et al., 2002; Hata et al., 2006; Dill et al., 2008). Consistently, CNS myelin and CSPG decreased the neurite length of CGNs, but treatment with PPAR $\gamma$ agonist GW1929 (10 $\mu \mathrm{M})$ or Ros $(10 \mu \mathrm{M})$ also significantly overcame the growth suppression of CNS axon growth inhibitors $24 \mathrm{~h}$ after cell plating (Fig. $4 A-C)$. Thus, PPAR $\gamma$ activation with selective agonists recovers neurite elongation in both peripheral and central neuronal cultures exposed to CNS axon growth inhibitors. The axon growth inhibition of CNS myelin and CSPG, however, are not completely blocked by PPAR $\gamma$ activation with agonists. The remaining axon growth inhibition by CNS inhibitors in the presence of PPAR $\gamma$ agonists may be attributable to a RhoA-independent pathway that regulates axonal extension (Fournier et al., 2003; Fu et al., 2007). Together, the results from these neurite growth experiments are consistent with our hypothesis that PPAR $\gamma$ activation represses RhoA signal in neuronal cells.

\section{PPAR $\gamma$ inactivation with its antagonist or knockdown with siRNA blocks RhoA-inhibiting function of ibuprofen in PC12 cells}

If PPAR $\gamma$ is a critical signal for mediating RhoA inhibition of ibuprofen in neurons, PPAR $\gamma$ antagonism with a selective pharmacological inhibitor should eliminate the RhoA-inhibiting property of this drug in neurons. To examine this mechanism, we evaluated the effect of PPAR $\gamma$ antagonist GW9662 on RhoA activity in differentiated PC12 cells. After pretreatment with GW9662 (10 $\mu \mathrm{M})$ plus ibuprofen $(500 \mu \mathrm{M})$ or non-Rho-inhibiting naproxen (400 $\mu \mathrm{M}$ ) for $1 \mathrm{~h}$, purified CNS myelin or CSPG was added to the PC12 cells for 30 min to stimulate RhoA activity. The levels of active RhoA in the lysates of PC12 cells were determined via precipitation with RBD beads as described above (Ren et al., 1999; Dubreuil et al., 2003; Fu et al., 2007). As anticipated, stimulation with CNS myelin $(50 \mu \mathrm{g} / \mathrm{ml} ; 30 \mathrm{~min})$ or CSPG $(1.5 \mu \mathrm{g} / \mathrm{ml} ; 30$ min) dramatically induced RhoA activation in differentiated PC12 cells treated with naproxen, whereas incubation with ibu-
C

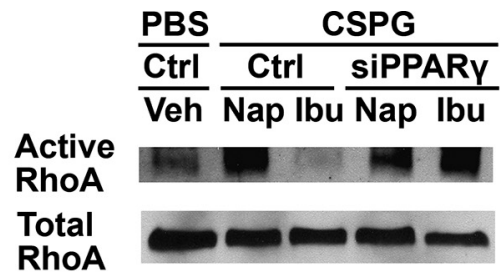

D

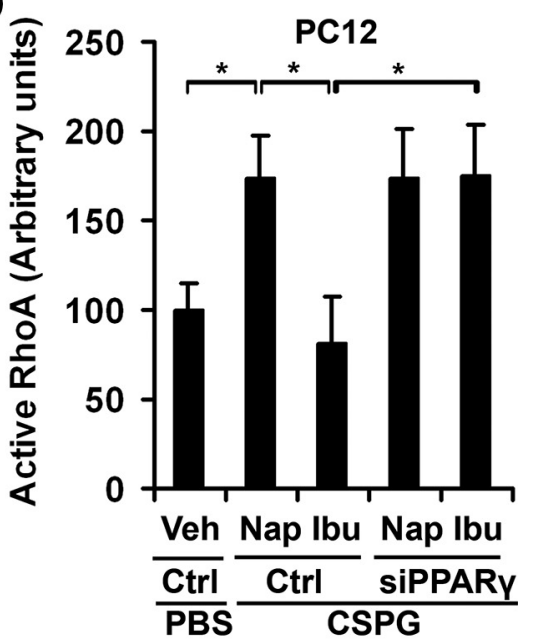

Figure 6. PPAR $\gamma$ knockdown with siRNA reverses RhoA inhibition function of ibuprofen in PC12 cells exposed to CNS myelin or CSPG. A, RhoA activity (top bands) was determined from the lysates of PC12 cells exposed to CNS myelin ( $50 \mu \mathrm{g} / \mathrm{ml} ; 30 \mathrm{~min}$ ) $4 \mathrm{~d}$ myelin $(\boldsymbol{A}, \boldsymbol{B})$ or CSPG $(\boldsymbol{C}, \boldsymbol{D})$. PPAR $\gamma$ knockdown with siRNA, however, abolished the RhoA-repressing function of ibuprofen. Means \pm SEM from three or four separate experiments were reported in each group. ${ }^{*} p<0.05$; ${ }^{* *} p<0.01$; Student's $t$ test.

profen $(500 \mu \mathrm{M})$ largely reversed RhoA activation (Fig. 5) (Fu et al., 2007). The PC12 cells treated with ibuprofen $(500 \mu \mathrm{M})$ plus the PPAR $\gamma$ antagonist GW9662 (10 $\mu \mathrm{M})$, however, exhibited high levels of active RhoA signal principally following stimulation with CNS myelin or CSPG (Fig. 5; supplemental Fig. 2, available at www.jneurosci.org as supplemental material).

To exclude the possible nonselective role of the PPAR $\gamma$ antagonist GW9662 and confirm the critical role of PPAR $\gamma$ in regulating ibuprofen-induced RhoA inhibition in PC12 cells, we evaluated whether PPAR $\gamma$ knockdown with the siRNA specific for PPAR $\gamma$ could mimic the effect of its antagonist. Four days after transfection with the siPPAR $\gamma$ or a control siRNA, PC12 cells were treated with naproxen $(400 \mu \mathrm{M})$ or ibuprofen $(500 \mu \mathrm{M})$ for $1 \mathrm{~h}$ and then stimulated with CNS myelin or CSPG for $30 \mathrm{~min}$. Consistently, downregulation of PPAR $\gamma$ remarkably reversed the RhoA suppression induced by ibuprofen following application of axonal growth inhibitors (Fig. 6). Thus, PPAR $\gamma$ suppression via a selective antagonist or protein knockdown with siRNA effectively blocks the RhoAinhibiting properties of ibuprofen in neuron-like cells.

\section{PPAR $\gamma$ antagonist blocks growth-promoting function of ibuprofen in primary neuronal cultures}

Suppression of RhoA activity with selective inhibitors or ibuprofen stimulates remarkable neurite growth in neurons (Fu et al., 2007). Given that the PPAR $\gamma$ antagonist GW9662 efficiently 
A

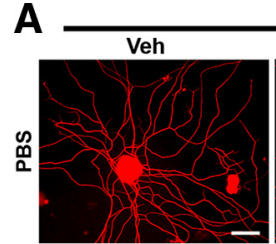

DRG
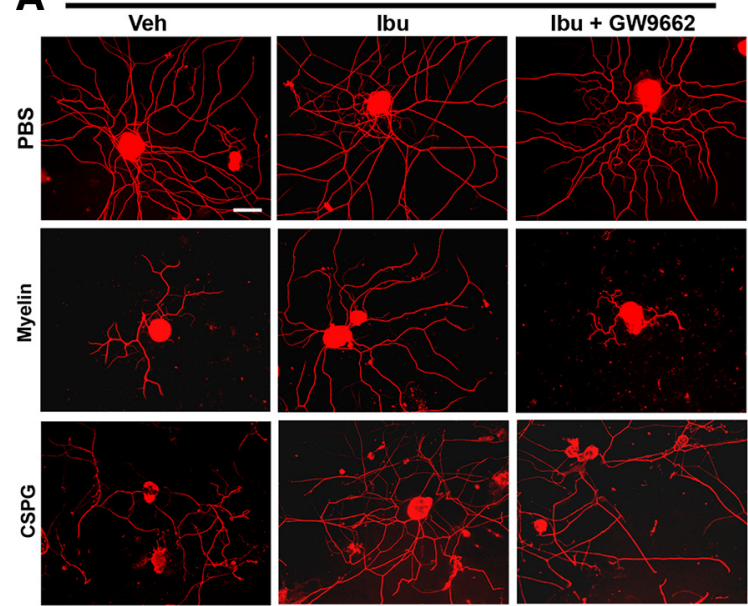

D PBS
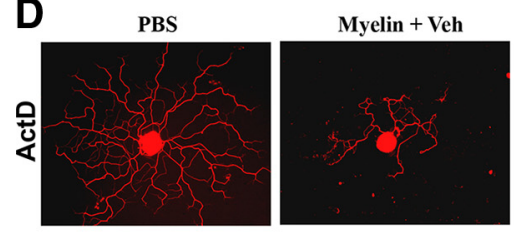
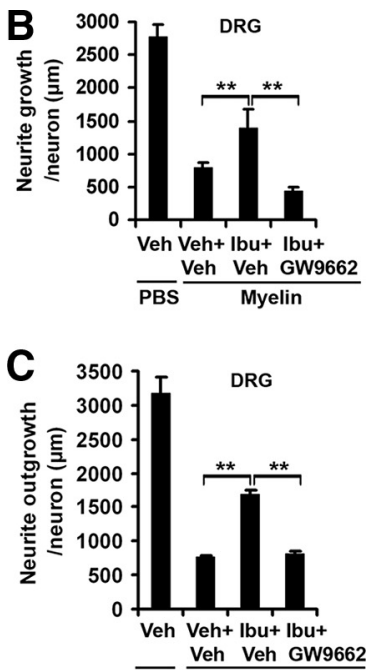
Veh Veh GW9662

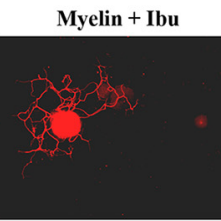

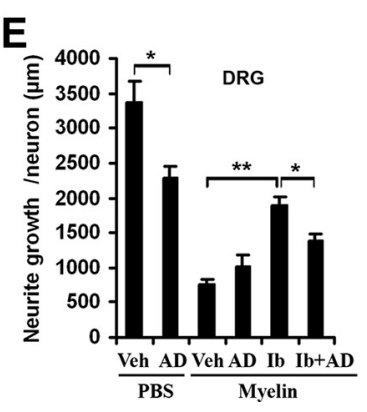

Figure 7. PPAR $\gamma$ antagonist GW9662 blocks neurite growth-promoting function of ibuprofen in DRG neurons cultured on CNS myelin or CSPG. $\boldsymbol{A}$, The representative DRG neurons from adult mice were treated with vehicle (Veh; left column), ibuprofen (Ibu; $500 \mu \mathrm{m}$; middle column) or ibuprofen plus GW9662 (Ibu + GW9662; $10 \mu \mathrm{m}$; right column) after cell plating in the absence (top row) or presence of CNS myelin (50 $\mu \mathrm{g} / \mathrm{ml}$; middle row) or CSPG $(1.5 \mu \mathrm{g} / \mathrm{ml}$; bottom row). Cells were fixed and stained with rhodamine phalloidin $24 \mathrm{~h}$ after growth. Scale bar, $50 \mu \mathrm{m}$. B, C, The bar graphs indicate neurite length per DRG neuron quantified $24 \mathrm{~h}$ after cell plating. GW9662 significantly blocked the neurite growth-promoting effect of ibuprofen (Ibu) in DRG neurons exposed to CNS myelin or CSPG. Veh, Vehicle. $D$, The representative DRG neurons from adult mice were treated with vehicle (Veh) or ibuprofen (lbu; $500 \mu \mathrm{m}$ ) plus ActD ( $20 \mathrm{~nm}$ ) in the absence or presence of CNS myelin ( $50 \mu \mathrm{g} / \mathrm{ml})$. Cells were fixed and stained with an antibody against Tuj-1 $24 \mathrm{~h}$ after growth. $\boldsymbol{E}$, Bar graph indicates neurite length per DRG neuron quantified $24 \mathrm{~h}$ after cell plating following different drug treatments. Actinomycin $D(A D)$ significantly prevented the neurite growth-promoting effect of ibuprofen (Ib) in DRG neurons on CNS myelin. Veh, Vehicle. Means \pm SEM from four to six separate experiments are reported in each group. ${ }^{*} p<0.05 ;{ }^{* *} p<0.01 ;$ Student's $t$ test.

blocks RhoA suppression by ibuprofen, treatment with this $\operatorname{PPAR} \gamma$ antagonist should prevent the neurite growth-promoting function of ibuprofen. We examined this hypothesis functionally by analyzing the effects of ibuprofen plus a PPAR $\gamma$ antagonist on neurite outgrowth in dissociated adult DRG neurons exposed to CNS axon growth inhibitors. CNS myelin strongly reduced neurite number and length of DRG neurons $24 \mathrm{~h}$ after growth. Treatment with ibuprofen $(500 \mu \mathrm{M})$ significantly recovered the neurite length of DRG neurons (Fig. 7A-C) (Fu et al., 2007). As predicted, PPAR $\gamma$ inhibition with GW9662 $(10 \mu \mathrm{M})$ prevented the growth-promoting function of ibuprofen in DRG neurons cultured on either CNS myelin or CSPG. To confirm this result in central neurons, we evaluated neurite growth of CGNs and also demonstrated that GW9662 largely blocked the neurite growthpromoting function of ibuprofen in CGNs exposed to axon growth inhibitors (Fig. $8 A-C$ ). Together, these experiments further support the essential role of PPAR $\gamma$ activation in mediating RhoA-inhibiting properties of ibuprofen in neurons.

To assess the effect of a general transcriptional inhibitor on ibuprofen-enhanced neurite outgrowth, in selected experiments we treated DRG neurons with ibuprofen and ActD, a polypeptide antibiotic widely used to inhibit transcriptional activities of cells. ActD alone moderately enhanced the branches of neurites but reduced the cell density of DRG cultures (data not shown) and the neurite length of survived neurons (Fig. $7 A, D, E$ ), even at low concentrations of $10-20 \mathrm{~nm}$. Similar to GW9662, transcriptional suppression with ActD significantly reversed the growth-promoting effect of ibuprofen in DRG neurons cultured on CNS myelin.

\section{Discussion}

$\operatorname{PPAR} \gamma$, a ligand-activated transcription factor in the nuclear receptor superfamily, is critical for regulating the metabolism of lipids and glucose, inhibiting expression of proinflammatory genes, preventing neuronal death, and reducing amyloid- $\beta 42$ generation. Some synthetic PPAR $\gamma$ agonists, including troglitazone, rosiglitazone, and pioglitazone, are important Food and Drug Administration-approved drugs for the treatment of patients with type II diabetes. A number of compounds, such as prostanoids, long-chain fatty acids, and antidiabetic thiazolidinediones, can also bind and activate PPAR $\gamma$ (Kersten et al., 2000). These PPAR $\gamma$-binding agents possess similar structural characteristics, including a lipophilic backbone and an acid moiety, usually a carboxylate. Certain NSAIDs, such as ibuprofen, fenprofen, and indomethacin, contain amphipathic carboxylates and have the structural features for PPAR $\gamma$ binding. Thus, these NSAIDs may interact with and directly activate PPAR $\gamma$ (Lehmann et al., 1997). In this study, using luciferase as a reporter we consistently demonstrate that ibuprofen is an effective activator of PPAR $\gamma$ in PC12 and B104 cultures, the cells with neuronal properties. In contrast, the NSAID naproxen did not significantly increase PPAR $\gamma$ activity in these cell lines, although it induced a slight trend of $\operatorname{PAAR} \gamma$ activation. Of note, one group reported that naproxen could enhance PPAR $\gamma$ activity in non-neural cells using the rat hepatoma H4IIEC3 cell line (Jaradat et al., 2001). We also examined the effects of naproxen on PPAR $\gamma$ activity in kidney fibroblast COS-7 cells and detected increased luciferase activity following naproxen $(400 \mu \mathrm{M})$ treatment (data not shown). Thus, naproxen can stimulate the $\operatorname{PPAR} \gamma$ signal in some non-neural cells, but it does not activate PPAR $\gamma$ significantly in cells with neuronal properties. Together, our result supports that ibuprofen, but not naproxen, is able to activate PPAR $\gamma$ efficiently in neuronal cells.

Another key issue is whether PPAR $\gamma$ activation is able to suppress RhoA activity in neuronal cells. We demonstrate that activation of PPAR $\gamma$ with its agonists GW1929 and rosiglitazone suppresses RhoA activation in differentiated PC12 cells and promotes neurite elongation in primary neuronal cultures exposed to different CNS axon growth inhibitors. Similarly, several studies have demonstrated a strong correlation between $\operatorname{PPAR} \gamma$ activation and a decrease in RhoA activity in non-neural cells. By 
measuring RhoA activity in cell lysates, two groups reported that activation of PPAR $\gamma$ efficiently suppressed Rho-GTPase in endothelial cells of brain microvessels or smooth muscle cells (Wakino et al., 2004; Ramirez et al., 2008). In contrast, blockade of PPAR $\gamma$ largely eliminates the RhoA-inhibiting function of ibuprofen and the growth-promoting effect of ibuprofen in neuronal cultures exposed to axonal growth inhibitors (Figs. 5-8). Together, our experiments support that ibuprofen suppresses Rho-GTPase in neurons via binding and activating the transcription factor PPAR $\gamma$. Notably, NSAIDs indomethacin and sulindac sulfide may inhibit RhoA activity (Zhou et al., 2003) via a similar mechanism, because these two agents have also been reported to activate PPAR $\gamma$ in some types of cells (Lehmann et al., 1997; Wick et al., 2002).

Our results support that PPAR $\gamma$ activation with the agonists GW1929 and rosiglitazone enhanced total neurite length in primary cultured neurons via RhoA inhibition. However, two previous studies suggest that PPAR $\gamma$ agonists rosiglitazone and troglitazone did not promote neurite growth in PC12 cells (Satoh et al., 1999; Kim et al., 2008). Several differences, including cell types, drug treatment time course, molecular mechanism for controlling neurite elongation, and PPAR $\gamma$ agonists, may contribute to the discrepancy among these studies. To provide more valuable information on axon regeneration, we analyzed the neurite outgrowth in mature DRG and premature cerebellar granular neurons in the absence of NGF. In contrast, the previous studies observed the neurite formation in PC12 cells, a type of immature pheochromocytoma cell derived from rat adrenal medulla, in the presence of NGF. The molecular mechanism for regulating neurite extension in $\mathrm{PC} 12$ cells differs from that in DRG and cerebellar neurons, because the former is highly NGF dependent. In our study, the cultured neurons were incubated with PPAR $\gamma$ agonists for $24 \mathrm{~h}$ instead of several to 10 days in the previous studies. Long-term PPAR $\gamma$ activation might induce side effects on cells because of a lasting stimulation on transcriptional activities. In fact, we detected the reduced cell density in cultured DRG and cerebellar neurons treated with GW1929 and rosiglitazone at concentrations $>10 \mu \mathrm{M}$ (data not shown). In addition, troglitazone, used in a previous study, might exhibit pharmacological effects different from those of GW1929 and rosiglitazone (Satoh et al., 1999).

By measuring active RhoA signal and neurite outgrowth following stimulation with axon growth inhibitors, our experiments support the strong correlation between PPAR $\gamma$ activation and RhoA suppression in neuronal cells. The molecular mechanisms for PPAR $\gamma$ suppression of RhoA activity in neurons remain unclear. It is likely that the Src homology region 2 -containing protein tyrosine phosphatase-2 (SHP-2) couples the RhoA-suppressing function induced by PPAR $\gamma$. SHP-2 is a protein tyrosine phosphatase widely expressed in the cytoplasm of multiple cells. It regulates cell signals triggered by various molecules, such as cytokines and growth factors. PPAR $\gamma$ activation by the agonists troglitazone and pioglitazone has been shown to increase the levels of SHP-2 dose-dependently in smooth muscle cells, probably via attenuation of membrane translocation of SHP-2 (Wakino et al., 2004). Also, activation of SHP-2 could restrict RhoA activation by dephosphorylating tyrosine residue of guanine nucleotide exchange factors and subsequently repressing the conversion of Rho-GDP into Rho-GTP (Schoenwaelder et al., 2000). In support of this hypothesis, PPAR $\gamma$ activation has been reported to increase the levels of SHP-2 and inhibit RhoA activity in smooth muscle cells (Wakino et al., 2004). Furthermore, suppressing SHP-2 activity via genetic approaches has been shown to elevate RhoA activity in fibroblast cells (Schoenwaelder et al., 2000). It will be of great interest to examine the potential role of SHP-2 in mediating the effects of PPAR $\gamma$ on RhoA.

RhoA and its downstream signals play central roles in regulating biological functions of various cells, including cell movements, growth, and cell-cell interactions (Etienne-Manneville and Hall, 2002). On the other hand, the Rho signaling pathway remarkably contributes to the pathological processes of numerous diseases, such as axonal growth failure after CNS injuries, amyloid- $\beta 42$ formation in Alzheimer's disease, migration and invasion of leukocytes into the CNS in multiple sclerosis, invasiveness and metastasis in cancer cells, and smooth muscle hyperreactivity in hypertension (Mueller et al., 2005). Thus, regulating the activity of the Rho signaling pathway represents an important target for therapeutic interventions of a number of diseases. In this report, our experiments support that PPAR $\gamma$ is a critical signal for ibuprofen-mediated RhoA inhibition, suggesting that activation of PPAR $\gamma$ might become an alternative approach for suppressing Rho activity in these disorders. In fact, both Rho inhibition and PPAR $\gamma$ activation have been shown to be of potential benefit in several disorders, including Alzheimer's disease, multiple sclerosis, cancers, and traumatic spinal cord injury (Walters et al., 2002; Zhou et al., 2003; Heneka et al., 2005; Klotz et al., 2005; Fu et al., 2007; McTigue et al., 2007). Given the functional link between PPAR $\gamma$ and RhoA signals, the observed 
favorable effects of PPAR $\gamma$ agonists may be attributed to the silencing of Rho signaling under some pathological conditions. In addition, our studies demonstrate the dramatic neurite outgrowthpromoting function of some PPAR $\gamma$ agonists in both peripheral and central neurons, suggesting that these agents may improve axonal regeneration following CNS axonal injuries. Given the frequent applications of some synthetic PPAR $\gamma$ agonists in diabetic patients and the well understood safety profile of these drugs, an effective therapy for CNS axonal injury patients may be developed using these readily available drugs.

\section{References}

Alabed YZ, Pool M, Ong Tone S, Fournier AE (2007) Identification of CRMP4 as a convergent regulator of axon outgrowth inhibition. J Neurosci 27:1702-1711.

Atwal JK, Pinkston-Gosse J, Syken J, Stawicki S, Wu Y, Shatz C, TessierLavigne M (2008) PirB is a functional receptor for myelin inhibitors of axonal regeneration. Science 322:967-970.

Brabeck C, Beschorner R, Conrad S, Mittelbronn M, Bekure K, Meyermann R, Schluesener HJ, Schwab JM (2004) Lesional expression of RhoA and RhoB following traumatic brain injury in humans. J Neurotrauma 21:697-706.

Chen L, Necela BM, Su W, Yanagisawa M, Anastasiadis PZ, Fields AP, Thompson EA (2006) Peroxisome proliferator-activated receptor gamma promotes epithelial to mesenchymal transformation by Rho GTPasedependent activation of ERK1/2. J Biol Chem 281:24575-24587.

Conrad S, Schluesener HJ, Trautmann K, Joannin N, Meyermann R, Schwab JM (2005) Prolonged lesional expression of RhoA and RhoB following spinal cord injury. J Comp Neurol 487:166-175.

de Jong D, Jansen R, Hoefnagels W, Jellesma-Eggenkamp M, Verbeek M, Borm G, Kremer B (2008) No effect of one-year treatment with indomethacin on Alzheimer's disease progression: a randomized controlled trial. PLoS One 3:e1475.

Dergham P, Ellezam B, Essagian C, Avedissian H, Lubell WD, McKerracher L (2002) Rho signaling pathway targeted to promote spinal cord repair. J Neurosci 22:6570-6577.

Dill J, Wang H, Zhou FQ, Li S (2008) Inactivation of glycogen synthase kinase- 3 promotes axonal growth and recovery in the CNS. J Neurosci 28:8914-8928.

Dubreuil CI, Winton MJ, McKerracher L (2003) Rho activation patterns after spinal cord injury and the role of activated Rho in apoptosis in the central nervous system. J Cell Biol 162:233-243.

Eriksen JL, Sagi SA, Smith TE, Weggen S, Das P, McLendon DC, Ozols VV, Jessing KW, Zavitz KH, Koo EH, Golde TE (2003) NSAIDs and enantiomers of flurbiprofen target gamma-secretase and lower Abeta 42 in vivo. J Clin Invest 112:440-449.

Etienne-Manneville S, Hall A (2002) Rho GTPases in cell biology. Nature 420:629-635.

Fournier AE, GrandPre T, Strittmatter SM (2001) Identification of a receptor mediating Nogo-66 inhibition of axonal regeneration. Nature 409:341-346.

Fournier AE, Takizawa BT, Strittmatter SM (2003) Rho kinase inhibition enhances axonal regeneration in the injured CNS. J Neurosci 23:1416-1423.

Fu Q, Hue J, Li S (2007) Nonsteroidal anti-inflammatory drugs promote axon regeneration via RhoA inhibition. J Neurosci 27:4154-4164.

GrandPre T, Nakamura F, Vartanian T, Strittmatter SM (2000) Identification of the Nogo inhibitor of axon regeneration as a Reticulon protein. Nature 403:439-444.

Hata K, Fujitani M, Yasuda Y, Doya H, Saito T, Yamagishi S, Mueller BK, Yamashita T (2006) RGMa inhibition promotes axonal growth and recovery after spinal cord injury. J Cell Biol 173:47-58.

Heneka MT, Sastre M, Dumitrescu-Ozimek L, Hanke A, Dewachter I, Kuiperi C, O'Banion K, Klockgether T, Van Leuven F, Landreth GE (2005) Acute treatment with the PPAR $\gamma$ agonist pioglitazone and ibuprofen reduces glial inflammation and A $\beta 1-42$ levels in APPV717I transgenic mice. Brain 128:1442-1453.

Jaradat MS, Wongsud B, Phornchirasilp S, Rangwala SM, Shams G, Sutton M, Romstedt KJ, Noonan DJ, Feller DR (2001) Activation of peroxisome proliferator-activated receptor isoforms and inhibition of prostaglandin
$\mathrm{H}_{2}$ synthases by ibuprofen, naproxen, and indomethacin. Biochem Pharmacol 62:1587-1595.

Kashfi K, Rigas B (2005) Non-COX-2 targets and cancer: expanding the molecular target repertoire of chemoprevention. Biochem Pharmacol 70:969-986.

Kersten S, Desvergne B, Wahli W (2000) Roles of PPARs in health and disease. Nature 405:421-424.

Kim JB, Wright HM, Wright M, Spiegelman BM (1998) ADD1/SREBP1 activates PPAR $\gamma$ through the production of endogenous ligand. Proc Natl Acad Sci U S A 95:4333-4337.

Kim SW, Choi OK, Chang MS, Shin CS, Park KS, Kim SY (2008) Thiazolidinediones inhibit the growth of PC12 cells both in vitro and in vivo. Biochem Biophys Res Commun 371:197-202.

Kim WY, Zhou FQ, Zhou J, Yokota Y, Wang YM, Yoshimura T, Kaibuchi K, Woodgett JR, Anton ES, Snider WD (2006) Essential roles for GSK-3s and GSK-3-primed substrates in neurotrophin-induced and hippocampal axon growth. Neuron 52:981-996.

Klotz L, Schmidt M, Giese T, Sastre M, Knolle P, Klockgether T, Heneka MT (2005) Proinflammatory stimulation and pioglitazone treatment regulate peroxisome proliferator-activated receptor $\gamma$ levels in peripheral blood mononuclear cells from healthy controls and multiple sclerosis patients. J Immunol 175:4948-4955.

Lehmann JM, Lenhard JM, Oliver BB, Ringold GM, Kliewer SA (1997) Peroxisome proliferator-activated receptors $\alpha$ and $\gamma$ are activated by indomethacin and other non-steroidal anti-inflammatory drugs. J Biol Chem 272:3406-3410.

Li S, Liu BP, Budel S, Li M, Ji B, Walus L, Li W, Jirik A, Rabacchi S, Choi E, Worley D, Sah DW, Pepinsky B, Lee D, Relton J, Strittmatter SM (2004) Blockade of Nogo-66, myelin-associated glycoprotein, and oligodendrocyte myelin glycoprotein by soluble Nogo-66 receptor promotes axonal sprouting and recovery after spinal injury. J Neurosci 24:10511-10520.

Madura T, Yamashita T, Kubo T, Fujitani M, Hosokawa K, Tohyama M (2004) Activation of Rho in the injured axons following spinal cord injury. EMBO Rep 5:412-417.

McGee AW, Strittmatter SM (2003) The Nogo-66 receptor: focusing myelin inhibition of axon regeneration. Trends Neurosci 26:193-198.

McKerracher L, Higuchi H (2006) Targeting Rho to stimulate repair after spinal cord injury. J Neurotrauma 23:309-317.

McTigue DM, Tripathi R, Wei P, Lash AT (2007) The PPAR $\gamma$ agonist Pioglitazone improves anatomical and locomotor recovery after rodent spinal cord injury. Exp Neurol 205:396-406.

Mi S, Miller RH, Lee X, Scott ML, Shulag-Morskaya S, Shao Z, Chang J, Thill G, Levesque M, Zhang M, Hession C, Sah D, Trapp B, He Z, Jung V, McCoy JM, Pepinsky RB (2005) LINGO-1 negatively regulates myelination by oligodendrocytes. Nat Neurosci 8:745-751.

Mueller BK, Mack H, Teusch N (2005) Rho kinase, a promising drug target for neurological disorders. Nat Rev Drug Discov 4:387-398.

Pasqualetti P, Bonomini C, Dal Forno G, Paulon L, Sinforiani E, Marra C, Zanetti O, Rossini PM (2009) A randomized controlled study on effects of ibuprofen on cognitive progression of Alzheimer's disease. Aging Clin Exp Res 21:102-110.

Ramirez SH, Heilman D, Morsey B, Potula R, Haorah J, Persidsky Y (2008) Activation of peroxisome proliferator-activated receptor $\gamma(\operatorname{PPAR} \gamma)$ suppresses Rho GTPases in human brain microvascular endothelial cells and inhibits adhesion and transendothelial migration of HIV-1 infected monocytes. J Immunol 180:1854-1865.

Ren XD, Kiosses WB, Schwartz MA (1999) Regulation of the small GTPbinding protein Rho by cell adhesion and the cytoskeleton. EMBO J 18:578-585.

Sarruf DA, Yu F, Nguyen HT, Williams DL, Printz RL, Niswender KD, Schwartz MW (2009) Expression of peroxisome proliferator-activated receptor- $\gamma$ in key neuronal subsets regulating glucose metabolism and energy homeostasis. Endocrinology 150:707-712.

Satoh T, Furuta K, Suzuki M, Watanabe Y (1999) Prostaglandin J2 and its metabolites promote neurite outgrowth induced by nerve growth factor in PC12 cells. Biochem Biophys Res Commun 258:50-53.

Schoenwaelder SM, Petch LA, Williamson D, Shen R, Feng GS, Burridge K (2000) The protein tyrosine phosphatase Shp-2 regulates RhoA activity. Curr Biol 10:1523-1526.

Schwab JM, Conrad S, Elbert T, Trautmann K, Meyermann R, Schluesener HJ (2004) Lesional RhoA ${ }^{+}$cell numbers are suppressed by anti-inflammatory, 
cyclooxygenase-inhibiting treatment following subacute spinal cord injury. Glia 47:377-386.

Suh JM, Zeve D, McKay R, Seo J, Salo Z, Li R, Wang M, Graff JM (2007) Adipose is a conserved dosage-sensitive antiobesity gene. Cell Metab 6:195-207.

Tanaka H, Yamashita T, Yachi K, Fujiwara T, Yoshikawa H, Tohyama M (2004) Cytoplasmic p21(Cip1/WAF1) enhances axonal regeneration and functional recovery after spinal cord injury in rats. Neuroscience 127:155-164.

Wakino S, Hayashi K, Kanda T, Tatematsu S, Homma K, Yoshioka K, Takamatsu I, Saruta T (2004) Peroxisome proliferator-activated receptor $\gamma$ ligands inhibit Rho/Rho kinase pathway by inducing protein tyrosine phosphatase SHP-2. Circ Res 95:e45-e55.

Walters CE, Pryce G, Hankey DJ, Sebti SM, Hamilton AD, Baker D, Greenwood J, Adamson P (2002) Inhibition of Rho GTPases with protein prenyltransferase inhibitors prevents leukocyte recruitment to the central nervous system and attenuates clinical signs of disease in an animal model of multiple sclerosis. J Immunol 168:4087-4094.

Wang KC, Koprivica V, Kim JA, Sivasankaran R, Guo Y, Neve RL, He Z (2002) Oligodendrocyte-myelin glycoprotein is a Nogo receptor ligand that inhibits neurite outgrowth. Nature 417:941-944.

Wang X, Budel S, Baughman K, Gould G, Song KH, Strittmatter SM (2009) Ibuprofen enhances recovery from spinal cord injury by limiting tissue loss and stimulating axonal growth. J Neurotrauma 26:81-95.
Weggen S, Eriksen JL, Das P, Sagi SA, Wang R, Pietrzik CU, Findlay KA, Smith TE, Murphy MP, Bulter T, Kang DE, Marquez-Sterling N, Golde TE, Koo EH (2001) A subset of NSAIDs lower amyloidogenic Abeta42 independently of cyclooxygenase activity. Nature 414:212-216.

Weggen S, Eriksen JL, Sagi SA, Pietrzik CU, Ozols V, Fauq A, Golde TE, Koo EH (2003) Evidence that nonsteroidal anti-inflammatory drugs decrease amyloid $\beta 42$ production by direct modulation of $\gamma$-secretase activity. J Biol Chem 278:31831-31837.

Wick M, Hurteau G, Dessev C, Chan D, Geraci MW, Winn RA, Heasley LE, Nemenoff RA (2002) Peroxisome proliferator-activated receptor- $\gamma$ is a target of nonsteroidal anti-inflammatory drugs mediating cyclooxygenaseindependent inhibition of lung cancer cell growth. Mol Pharmacol 62:12071214.

Yamagishi S, Fujitani M, Hata K, Kitajo K, Mimura F, Abe H, Yamashita T (2005) Wallerian degeneration involves Rho/Rho-kinase signaling. J Biol Chem 280:20384-20388.

Zhao Y, Patzer A, Herdegen T, Gohlke P, Culman J (2006) Activation of cerebral peroxisome proliferator-activated receptors gamma promotes neuroprotection by attenuation of neuronal cyclooxygenase- 2 overexpression after focal cerebral ischemia in rats. FASEB J 20:1162-1175.

Zhou Y, Su Y, Li B, Liu F, Ryder JW, Wu X, Gonzalez-DeWhitt PA, Gelfanova V, Hale JE, May PC, Paul SM, Ni B (2003) Nonsteroidal antiinflammatory drugs can lower amyloidogenic $\mathrm{A} \beta 42$ by inhibiting Rho. Science 302:1215-1217. 